\title{
Everything You Always Wanted to Know (but were afraid to ask) About Evolution
}

\author{
Am I a Monkey? Six Questions about Evolution, by Francisco Ayala. Baltimore, MD: \\ Johns Hopkins University Press, 2010. Pp. xii + 83. H/b \$12.95
}

\section{Haley Moss Dillon}

Published online: 6 December 2011

(C) Springer Science+Business Media, LLC 2011

"Nothing in biology makes sense except in the light of evolution." - Theodosius Dobzhansky.

Whether you're a novice interested in the basic fundamentals of evolution or an exhausted graduate student tired of thinking of new ways to explain "what you do," Ayala's Am I a Monkey concisely provides a brief introduction/history of evolution and what it means to have evolved. Ayala organizes the book through six sections, answering six major questions:

Am I a Monkey? No, you are not a monkey, nor am I. Ayala begins his first section with the statement that he is a primate, and that monkeys are primates, but he is not a monkey. It is elementary-school wisdom that a square is a rectangle, but a rectangle is not a square. With the very first sentence, Ayala begins to sketch the greater tree of life, demonstrating a line of primates and their varying degree of relatedness to our Homo sapiens. Ayala targets a major selling point of the creationist movement: the missing link. There is no longer a missing link; Ayala discusses the fossil record that has been collected in the last century, from the earliest hominid fossils, Sahelanthropus and Orrorin to the current $H$. sapiens.

Why is evolution a theory? Evolution is a theory the way gravity or heliocentricism are theories. Ayala explains that evolution is a "theory" in a scientific manner of speaking, in that it is "a well-substantiated explanation of some aspect of the natural world that incorporates observations, facts, laws, inferences, and tested hypotheses" (p. 17). The way "theory"

\section{H. M. Dillon $(\bowtie)$}

SUNY New Paltz,

314 JFT, 1 Hawk Dr.,

New Paltz, NY 12561, USA

e-mail: haleymoss@gmail.com is defined in the scientific community is much closer to "fact" than the word "theory" is defined in general day-to-day language. Ayala explains that evolution is not a theory in that it is a "hunch" or an unsupported hypothesis, but that it is merely scientific semantics that designates evolution as a theory. "Evolution is just a theory" is one of the single most frustrating phrases truth deniers (anti-evolutionists) can utter. Ayala gives a new reason to ignore such statements - the fact that the theory of evolution is in fact, a fact.

What is DNA? Most people know that DNA is genetic code, a chemical structure in the shape of a double helix. The genetic information embodied in DNA accounts for the biological fundamental aspects of life: evolution and heredity. Ayala briefly describes the genome and the function of DNA before reaching the crux where DNA becomes evolution: mutation. Genetic mutation is how evolution occurs; without mutations there would be no change, and change is the essence of evolution.

Do all scientists accept evolution? Contrary to Michelle Bachman's delusional belief, the majority of biologists do accept evolution. Those who are aware of the evidence for evolution, Ayala says, cannot deny it. Ayala puts science into legal terms - he explains that "the evolutionary origin of animals and plants is a scientific conclusion beyond a reasonable doubt" (p. 49). The fossil record, the intermediates, and "missing links" are discussed, all the while Ayala bringing up various other scientific disciplines which help support the theory of evolution.

How did life begin? Ayala states that almost all biologists agree that life originated spontaneously. Further, he states that scientists agree that all organisms living on Earth have derived from a single original form of life. Ayala asks, what is life?-a question that must be answered in order to later determine how it began. Life, Ayala explains, is a combination of cells and metabolism. 
Can one believe in evolution and God? Doctor William Tooke, in his lectures on the history and systems of psychology at SUNY Plattsburgh once stated: "one cannot believe in evolution while maintaining belief in a literal translation of the Bible." Ayala makes a similar point; "a literal interpretation of Genesis seems incompatible with the gradual evolution of humans and other organisms by natural processes" (p. 74). Both Drs. Tooke and Ayala are pointing out that it is not the Bible that creates an anti-evolutionary thought process, it is the literal interpretation that causes problems both within an individual's belief system and in society as a whole. Ayala demonstrates examples in history of religious organizations finding compatibility with evolution. Pope Pius XII, in 1950, asserted that biological evolution is compatible with the Christian faith. Pope John Paul II is also quoted by Ayala in favor of evolution. Further, The General Assembly of the United Presbyterian Chuch in 1982 adopted a resolution stating that biblical scholars have found that the scientific theory of evolution does not conflict with their [the biblical scholars] interpretation of the origins of life as stated in biblical literature (p.75).

Ayala asserts that he is convinced that evolution and religious beliefs need not be in contradiction. Ayala goes so far as to suggest that if science and religion are properly understood, they cannot be in contradiction, for they concern different matters (p. 73). Ayala concludes that yes, one can believe in both evolution and God; "evolution is a well-corroborated scientific theory. Christians and other people of faith need not see evolution as a threat to their beliefs" (p.82-83) and finalizes his statement by paraphrasing Aubrey Moore; "evolution is not the enemy of religion, but rather, its friend" (p. 83).

Ayala not only provides answers to basic evolutionary questions, he provides examples that allow inclusion of lay persons. During my reading of this work, I found myself wanting to change the title from Am I a Monkey? to A Brief Description of What I Base my Research on. Ayala manages to do something many scholars cannot: he is able to explain an entire theory in a concise, relatable manner.

While Ayala describes mutations and their effect on evolution, he doesn't go into how the mutations occur, which is a major question when explaining evolution. It is common knowledge among evolutionary studies academics that mutations are behind much of evolution, but the actual causes of the mutations are not as widely known. Overall, had Ayala included more on the causation of mutations, his story would have been more cohesive.

This book is useful for anyone interested in evolution. It is a handy pocket-sized explanation of a theory, useful for evolutionary scholars to explain the fundamentals and not get lost in their particular area of interest, useful for college (possibly even high school) teachers to provide a foundation of evolutionary theory, and is topical enough to pull in readers of all disciplines. This book will certainly make its way to my future syllabi. 